\title{
Complicated gratitude: a letter to my mother's physician
}

\author{
Cite as: CMAJ 2020 January 27;192:E97-8. doi: 10.1503/cmaj.191259
}

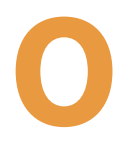

$\mathrm{n}$ the morning you administered medical assistance in dying (MAiD) to my mother, you kindly and gently explained what we could expect. You reassured us that she would feel no pain, but rather drift off to sleep quickly. You entered my mother's room and greeted her warmly. You took in the scene: family members sitting in every chair that was permitted to be in the hospital room. You graciously turned down the glass of scotch we offered you - the scotch we poured to toast my mother. You knelt beside the bed, holding my mother's hand, and asked her whether she wished to go ahead. She assented. You encouraged us to embrace her as she took her final breaths. When my mother died, you leaned down to the bed where my sister and I lay, holding our mother, and quietly informed us that she had passed. And at our request, you opened the window so that her soul could escape the hospital room. With utmost respect, you fulfilled my mother's final wish - to die with dignity.

In the minutes, hours and first few weeks following my mother's death, I could not help but think of you as her executioner. In the final days of her life, following her decision to formally request MAiD, my mother's longstanding delirium cleared. The mother I remembered from childhood, with her sharp wit and hearty laugh, reappeared before my eyes. She was no longer the confused, paranoid, hostile and forgetful person I had come to resent over the last several months.

And here you were to help steal her away, once and for all. Your clinical offering to fulfill her last wish of dying with dignity - and its finality - brought her back to life. The irony wasn't lost on me.

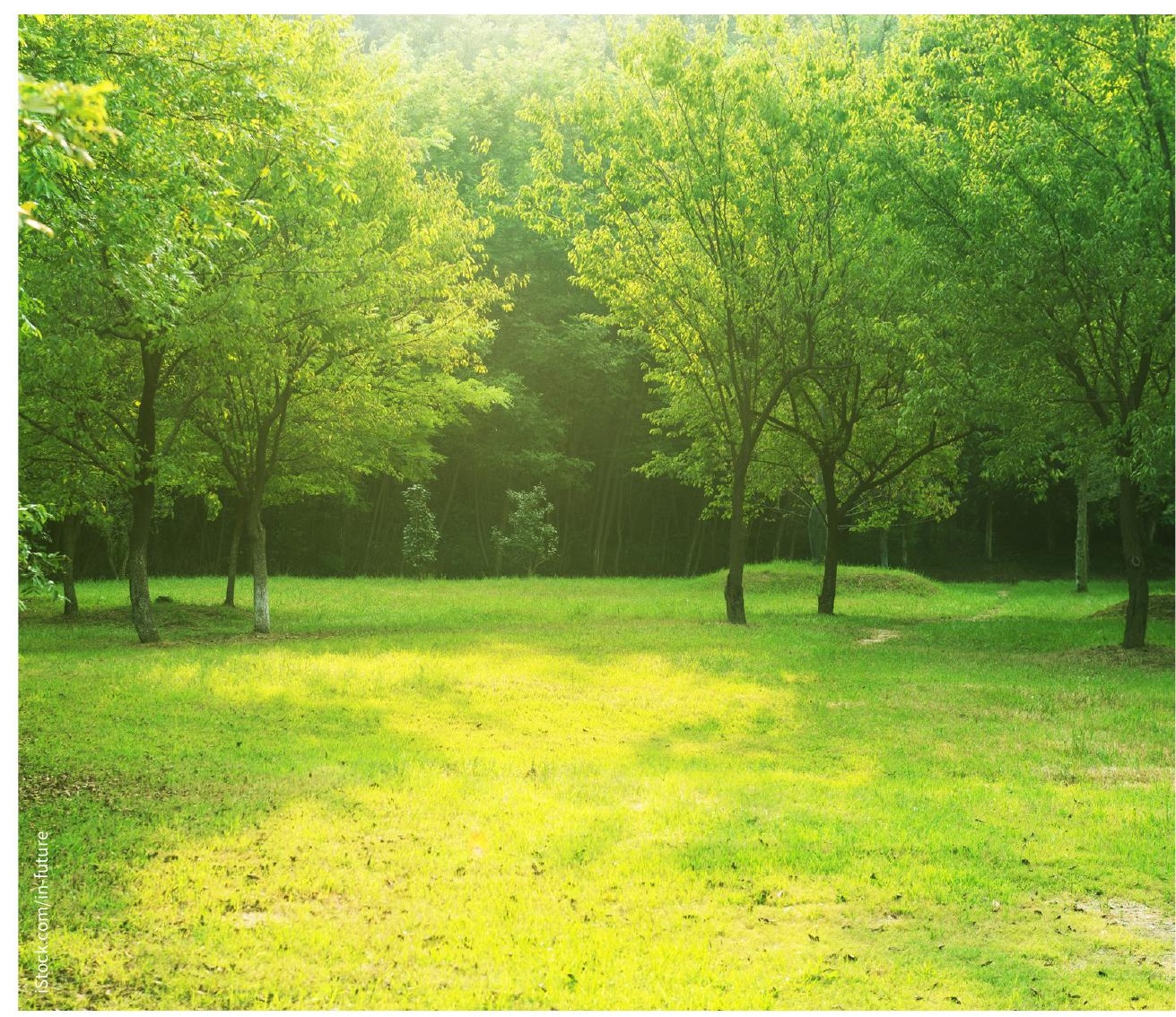

Six months earlier, our mother was in the intensive care unit on the brink of death. We discussed end-of-life care and planned a funeral. I stood by her bedside, held her hand, and told her I loved her and that I forgave her. I told her she could let go. But for better or for worse, she fought like hell to live, and we brought her home.

On the day you provided MAiD, as you arranged the supplies, I quickly flashed back through the last six months. My thoughts lingered on my mother's final days spent recounting 69 years' worth of memories and wisdom.

"Should we sing something?," my sister wondered aloud.
I buried my head in the crook of my mother's ankles, eyes clamped shut, and we began to sing "What a Wonderful World" - the same song my sister sings to my infant nephew before he naps.

I was entirely unaware of your presence behind me, and was reminded only when you put your hand on my shoulder. For an executioner, you have a gentle touch.

You relieved my mother of the endless breathlessness caused by her endstage chronic obstructive pulmonary disease. You enabled her to rest and slumber peacefully for the first time in months, if not years. I took comfort in 
the fact that you fulfilled your professional duties ethically, within the parameters of the legislation. You allowed my mother to have a good death. An ethical death. A compassionate death, free of the suffering she experienced in life.

In the moments following my mother's death, our family held one another and sobbed. You offered condolences. We bowed our heads slightly. I felt gratitude for the privilege of living in a country that provides for its citizens in life and until death.

My mother is gone, but you didn't take her. Her illness robbed her of her stamina, strength, and dignity. She was riddled with pain and suffered immensely. You alleviated her suffering. But in her relief, we suffer the loss.

I conclude my letter to you, doctor, with deep gratitude - gratitude for your humanity, your compassion and your ethics. I no longer see you as my mother's executioner. You were her saviour.

\section{Rachel B. Cooper BA (Hons)}

Centre for Addiction and Mental Health, Toronto, Ont.

This article has been peer reviewed.

Consent to publish this article has been received from the attending physician and the author's family. 